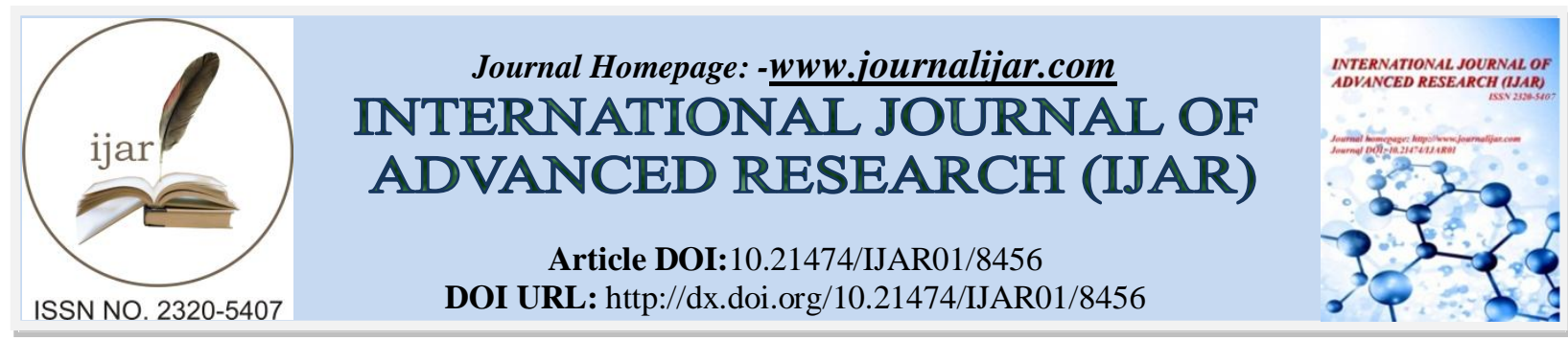

RESEARCH ARTICLE

\title{
A STUDY OF EMPLOYEE PERCEPTIONS OF OUTSOURCING OF INFORMATION TECHNOLOGY OPERATIONS IN BANKING SECTOR.
}

Amila Bandarawatta ${ }^{1}$ and Prabu Premkumar ${ }^{2}$.

1. Postgraduate Department, International College of Business and Technology, Kandy, Sri Lanka.

2. Faculty of IT and Science, International College of Business and Technology, Kandy, Sri Lanka.

\section{Manuscript Info}

Manuscript History

Received: 02 December 2018

Final Accepted: 04 January 2019

Published: February 2019

Key words:-

Outsourcing, Employee Perception,

Information Technology.

\section{Abstract}

The Information Technology (IT) outsourcing poses a potential job loss threat to IT professionals. This study investigated the perception level of employees directly involved in IT outsourcing, deals in an effort to relate these perceptions to factors identified in earlier studies. The following human resource factors associated with outsourcing were evaluated: skills, control, job security and job satisfaction. The study uses an adopted model from a previous study and evaluated four hypotheses that contended differences in perception in terms of demographic factors. The study used survey questionnaire to collect primary data from the entire population of 52 permanent employees of IT department of a leading private bank. The collected data was analyzed by the use of descriptive and inferential data analysis methods. It was revealed that permanent employees in this organization had a negative perception towards IT outsourcing. Further the results show employeesbelongs to different age levels have significantly different level of perception on IT Outsourcing.

Copy Right, IJAR, 2019,. All rights reserved.

\section{Introduction:-}

The outsourcing practices help businesses to save their resources, money and maintain service quality. However most of the organizations not concern about human considerations, when taking and implementing outsourcing decisions. As a result it adversely affects the employees in the organization, mostly their job security and satisfaction which increase job stress, ambiguity and increase employee turnover. This adds a negative effect to competitive advantage generated from outsourcing.Importantly Information Technology (IT) outsourcing involves company downsizing which directly engages on cost savings. On the other hand, losing jobs have rippling social and economic consequences. According to Rosen and Ganster (2013) at present majority of individuals spend most of their time in their jobs and they do not like to experience unfavorable experience at work regarding change of behaviors, relationships and attitudes. Therefore employee's wellbeing depends on their jobs and it makes significant effects on their social life. Some outsourcing decisions may drive employees to work related stress and fear of losing employment. The job stress is an important topic that every industry should concern that can ultimately damage individual's psychology and physical health. The work related stress decreases work performance and that lead to low productivity.

Corresponding Author:-Amila Bandarawatta.

Address:-Postgraduate Department, International College of Business and Technology, Kandy, Sri Lanka. 
There are many previous literatures which depict IT outsourcing allows enhance in productivity and more focus on service delivery (Chang \&Gurbaxani 2012). According to a study IT outsourcing supports to organization's cost reduction, service delivery effectiveness and efficiency plus employee loyalty (Galanaki, et al., 2008). The outsourcing of Information Technology(IT) operations has an annual growth rate of 14\% and around 67\% of IT accounts produced from outsourcing market valued 500 billion (Gorla, et al., 2014). According to Robinson (2016), United States has outsourced 3.3 million jobs globally and out of this 500,000 are IT jobs. However researches state employees of some organizations see outsourcing as a threat that fire full time employees and given opportunity to workers in developing countries who work for low wages.

The outsourcing of IT operations of financial institutions such as banks needs to be done with utmost care. The banks have utmost responsibility of protecting customer confidentiality. The banks are bounded by numerous data protection and privacy rules and policies to safeguard privacy of transactions without exposing information to the third parties. At present all the information gathering, processing, storing and retrieving handle through computer systems. Any kind of valued information disclosure may expose organization to reputation and operational risk. It could bring down trust and confident level of customers about the organization, especially this may affect the whole financial system as well as economy. Outsourcing sensitive IT functions should be done after proper analyzing and planning. Agreements, contracts, continuous monitoring for information breeches and corrective actions should bedone for IT security regarding with outsourcing practices (Piyasena, 2006). Further it is pointed out that as a trend many Sri Lankan banking organizations begin negotiating contracts with outsourcing IT vendors to reduce operational costs.

According Piyasena(2006) at present Sri Lankan banks seek many ways to outsource various IT operations. Heconsiders one of the significant successes of outsourcing in Sri Lankan banking sector as "Lanka Clear" Cheque clearing system. Same author states some of the challenges in outsourcing practices that Sri Lankan banking sector should mindful are losing confidentiality of banking transactions and transfer risk of banking functions to outsourced staff. Further the author states outsourcing result large scale staff lay-offs and that may lead to employee union actions and ultimately enhanced resistance to the process. Outsourcing services related with banks are exposed to risks related to reputation, contract, operations and strategy (Barako, et al., 2008).

The majority of studies done on the topic of outsourcing deals with factors such as, selecting vendors, issues, risks, contracts types, limitations and rationale. However attitudes of employees about outsourcing had a limited focus on past researches. When it comes to Sri Lankan banking industry this a new area to conduct a study and the finding could be more valuable to decision makers in banking industry and other industries. IT is a costly business hence the advancement of its equipment and specialized knowledge. Therefore hiring qualified IT professionals and retaining them need higher quota on IT budget. Mostly IT related works are not bound only to the office working hours hence it is a more prone with over time and substantial payments. Therefore cost reduction might focus on these factors towards decreasing salaries and find ways to lower costs using external service providers by outsourcing. The direct linkage among IT outsourcing and employee perception is a highly sensitive and an important topic within the IT industry that far worth for further investigation. This research focused on IT outsourcing to Sri Lankan banking context. Hence, this study carries out investigated findings of employee perception on IT outsourcing at banking sector.

\section{The major objectives of this study are:}

1. Establish the level of perception of internalIT employeeson IT outsourcing.

2. Determine the differences in perception on IT outsourcing of internal IT employees in terms of demographic factors

3. Provide recommendations to create a positive perception about IT outsourcing among internal IT staff.

\section{Review ofLiterature:-}

It is said that outsourcing is a strategic decision to achieve cost reduction, quality enhancement and increased productivity (Gray, et al., 2009). It helps to improve productivity of employees and morale. Further, it allows organization to refocus on their core business and create positive corporate image. Further outsourcing helps organizations to enhance efficiency, quality, and functional expertise and reduce competitive pressure and internal administrative problems (Fill, et al., 2000). Winkleman (1993) states outsourcing allows getting a new value to an organization by having a strategic shift in direction of managing businesses. It is also noted that outsourcing allows 
organizations to seek benefits (Dhar, et al., 2006) especially cost reduction. Further researches state outsourcing helps organizations to identify various issues and allow addressing those issues.

\section{Outsourcing in banking industry}

There are very limited numbers of research articles found in associate to the topic of outsourcing practice related to the banking industry. A study on United States banking sector discovered poor performance is a considerable determinant to exercise outsource operations to get back into better position (Ang, et al., 1998). Another study at German reveals banks exercise outsourcing to achieve competitive advantage by cost reduction (Fritsch, et al., 2007). In 1999, New York Federal reserve bank has done a survey on outsourcing practices in banking industry found out, cost reduction, enhancing performance, gaining strategic capabilities, gaining greater expertise are the main factors influenced for outsourcing. At the same time it raises potential risks such as compliance, reputation loss, transnational, strategic and country risk. Similar to the previous survey, the Federal bank of San Francisco conducted a survey to find motives on outsourcing of financial institute (Lopez, 2004). The study delivered outcomes such as efficient in operations; utilizing resources efficiently and fast service delivery in reliable manner are the factors influencing outsourcing. Also a similar survey conducted by European central bank disclosed similar results of outsourcing benefits (European central bank, 2004). All those surveys uncovered outsourcing practices introduce more challenges and risks than the benefits in the banking industry. Both US and European studies revealed benefits of outsourcing such as cost reduction, access to better resources and technology, able to focus on organization core activities, enhanced quality of service, flexibility, economies of scale advantage to improvement in major services and saving company resources. Both studies revealed several risks associated with outsourcing such as operational, reputation loss, legitimate, strategic and country risks, cultural problems, control loss, flexibility loss, organization conflicts, and behavioral problems. A survey study in financial service industry at European Union reveled banking organizations may prefer to outsource non key activities for various intentions (Pujals, et al., 2004). Several motives mentioned in the study such as operational cost reduction, improving service quality, superior flexibility and an access to modern technology. Same time following risks can be associated with outsourcing such as operational risk, loss of control over operations, reputational risk, cultural and social mismatches, loss of flexibility, and loss of internal skills, dropping quality of service standards, decline competitive advantage, and technical constraints. However, when it comes to outsourcing practices in developing countries some factors may change according to country specific reasons.

\section{IT Outsourcing}

IT outsourcing can be defined as using the external service providers effectively to deliver IT enabled services, infrastructure solutions and business processes for business deliverable (Gartner IT Glossary, 2017). In brief IT outsourcing is defined as a delegation IT related duties to the third parties to do it better in faster manner and cheaper cost. The outsourced functions can beseparated into two main types according to the level of control over performance (Palvia, et al., 1995). The functional relocation in business for enhancing performance and gain strong control considered as internal outsourcing including partnerships, long term and short-term partnerships. The delegation of performance to external service provider, separated or mutually related functions consider as external outsourcing, which include cooperation, outsourcing center concept and partnership in capital.

Recently outsourcing has become a critical part of the organization strategy that offers productivity, quality, performance, competitive advantage, specialized knowledge and technical skills (Robinson, 2016). It is considered that IT sector is the most outsourced sector among others (Duhamel, et al., 2014). Robinson (2016) stated in his study that the most outsourced IT functions as web development, tech support, telecommunication, system operation and planning. According to research findings outsourcing decisions based on inefficient internal IT functions (Lacity, et al., 2012). Lack of technical expertise, less knowledge about the field and limited resources are notable factors drive for outsourcing decisions. Fung (2013) stated outsourcing help to focus businesses on their core activity by outsourcing less knowledgeable activities. Further outsourcing provides new technical expertise to the organization, which was not available previously (Rose-Anderssen, et al., 2011). The vendors supply additional resources to fulfil organization requirements and expertise to improve productivity and enhanced IT related knowledge of internal employees. Ultimately outsourcing act as a gap filler of organization deficiency requirements.

\section{Employee Perception}

Perception can be simply elaborated as a perspective of an individual which has based on their personal view about a particular situation. Perception is a psychological construct that is very hard to define precisely associated with attitudes and emotions (Vithessonthi, 2005). Further, it is also stated perception as a process, which provides 
organized interpretation of employee's impression in order to their environment, and it influences employee's work place behavior (Langton, et al., 2006). Berelson define perception as a complex process of selecting, organizing and interpretation of meaningful sensory stimulation what the person pictures about the world (Berelson, et al., 1964). Also it is explained as an interpretation of information provided by our senses in an organized manner (Barber, et al., 1976). Several researchers define perception by the employment and organizational point of view. Bartlett (2004) was a notable researcher on that field of study. Bartlett argued conventional thinking influences perception of human ways of generic beliefs about the shape of information and influence of world. Previous research discussions render individual perception is psychological perspectives that influence their outcome of decisions; thus it is important to find relationship between perception and organizational aspects. Perception influences employees rational about the organization certainty or uncertainty hence the organization strategies should change according to it (Anderson, et al., 1975).

Employee perception may change according to the working environment. Modern organizations coordinate, supervise and allocate tasks toward a structure to achieve organizational targets. The departments are specialized divisions on the organization structure handled specialized tasks. Within departments there are sub departments divided according to the nature of specialized work. These departments consistof various percentages of outsourced employees to handle various types of IT work. Therefore the department can take as a variable which affects internal staff perception on outsourcing.

At present, IT outsourcing emerges with many job roles. In an organization job roles in some departments are completely or partially handled by the outsourced employees. According to Ang \& Slaughter (2000), changes in job role are very likely to have impacts on employee perception. Job roles are bound with employee's psychology and it seems to affect the cognition of employees about the working environment. Madsen, Miller \& Cameron (2005) elaborate job role, its involvement and its context perceived employee's willingness to support to organization success. Along with satisfied job roles organization is able to incur employee's full capacity of work. Chen (2008) describes job satisfaction as perception, attitudes and feelings come from the employee's job role in the organization. Since outsourcing is an organizational change, losing some job roles with regard to the outsourcing practices may affect internal employee perception. Based on research model of Weber and Weber's job associated attitudes like job satisfaction, job involvement, jobsecurity, commitment and job related characteristics like task variety, goal clarity, task significance, and feedback affect employee perception (Vithessonthi, 2005).

Employees are gained experience while working in a specific field in an occupation and that can be defined as work experience(Itmanagerdaily,2017). According to the job characteristic theory(Hackman et al, 1980) corejob related experience and characteristics are linked directly to employees' perception and psychological state. It further explained the degree of skill variety, the number of different activities performing at work, extent of job description and talent are considered as basic factors which define job experience. Further they elaborate work that improves employee's abilities and skills in consistent manner provide more meaningful experience than simple routine works also it is substantial to the physical and psychological wellbeing. Employees with various level of job experience perceive different cognition about the organization decisions. Due to outsourcing decisions internal employees grasp different attitudes and perception according to their work experience.

IT related work needs some formal education and specialized education related to specialized fields. The qualifications fulfill the job requirements for performing job in productive manner. Qualifications often decide the employees stand and position within the organization also their compensation and benefits. Becker (1964) elaborates individuals who acquired higher ability and knowledge more likely to reward with higher earnings. Kanfer\&Ackermen (2004) state intelligence gained by qualifications refers to the employee perception. The qualifications gain from education enhances cognitive ability, job knowledge and help to maintain high moral standards (Bear, et al., 2003). At present many organizations tend to replace qualified experts by outsourced experts at a lower cost which affect permanent employee perception.

Cooper (2009) conducted a huge survey using 5000 employees to test the work life quality. It revealed a major restructuring change like outsourcing or downsizing adversely affect employee morale, loyalty, motivation and job security. Palvia\&Parzinger (1995) elaborate employees often feel jobs insecurity because it is very common in reduction and staff cuts in outsourcing process. HR focus magazine issue of august 2009 explains employee perception regarding to job security as a series of psychological process and behavioral responses entail with it. Theemployees go through feelings such as insecurity, anger, depression, unfairness, fear, grief and guilt regarding 
job downsizing when outsourcing process taken into consideration. Further, they define it as "Survivor syndrome.Solinger, Olffen\& Roe (2008) carried out a qualitative study using information system employees and discovered significant factors related to job satisfaction. Outsourcing activities had negative effect on employees' future certainty and morale. This study found out employees fear about lay-offs, loosing benefits, future outsourcing plans and transfers. They recommend management to address such doubts of employee's otherwise low productivity and personal exodus may be resulted. This proves outsourcing process caused job dissatisfaction, anxiety and insecurity to participants which drive them to seek employment opportunities elsewhere (Palvia, et al., 1995). Further the research states employees perceive outsourcing as a threat and usually it take six months to one year to get familiar with the process.

\section{Methodology:-}

The influences of job role, work experience, educational qualification, and age on employee perception of IT outsourcing were discussed in the previous literatures. Based on this a conceptual framework is derived in order to realize the objectives of the research by developing research hypothesis. In this model job role, work experience, educational qualification, and age are selected as independent variables and employee perception on outsourcing is taken as dependent variable.

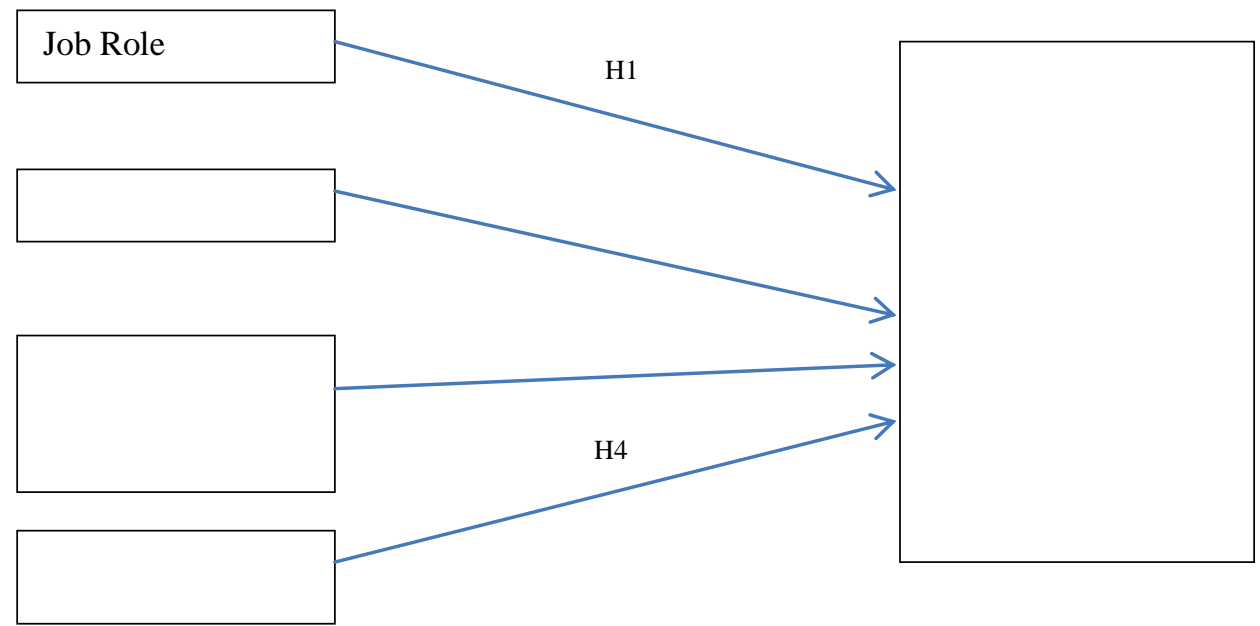

Figure 1:-Conceptual Framework on Employee perception on IT outsourcing

\section{Development of Hypotheses}

Following are the Hypotheses developed for the research study.

H1: Employees handling different job roles have significantly different level of perception on IT outsourcing.

H2: Employees have different job experiences having significantly different level of perception on IT outsourcing.

H3: Employees with different educational/ professional qualifications have significantly different level of perception on IT outsourcing.

H4: Employees of different age levels have significantly different level of perception on IT outsourcing.

\section{Research Design}

This study takes a deductive research approach in order to achieve the objectives of the research because it is used the existing theories and practices to certain phenomena to test and thereby to give conclusions and recommendations.

\section{Population and Sampling}

The researches objective is to of determine the permanent employee's perception about IT outsourcing. Therefore the population for the research only had to consider all the 52 permanent employees at Information Technology Department of a leading private bank. 


\section{Data collection methods}

The collection of primary data made through a questionnaire included 23 questions. Data was gathered from the selected segment by the questionnaire which consists of two parts. Information regarding demographic information was collected through section 'A' by using 7 questions. Section 'B' included multiple questionnaire formats to mark the choice for target segment. It composed 16 questions which having Likert type scale 1- 5 to record responses to 4 independent variables and 1 dependent variable. TheQuestionnaire was prepared by adopting 14 survey questions of A. Maigua(2015) (Questions numbers 1- 5, 8,9, 11 to 14, 16 and 20) and 7 questions from Louis(2002) (Question numbers $10,15,17,19,21$ to 23$)$.

The reliability analysis conducted for the collected survey data by Cronbach's alpha test. The alpha value is greater than standard figure of 0.70 . Therefore the data collected was adequate and acceptable. The data was analyzed by using descriptive and inferential data analysis methods; this was done with the aid of Statistical Package for Social Science (SPSS).

\section{Data Presentation and Analysis:-}

Majority of the respondents of the questionnaire were male (88\%), and aged between 30 to 49 . Also it is noted that $50 \%$ of them are bachelor's degree holders and further $31 \%$ of them have master's degree. Further most of them are under 10 years of work experience. About 54\% of the respondents are in the lower management category while 44 $\%$ of them are in the middle management category. Exactly $75 \%$ of the respondents are from IT Operations division and rest from IT Research and Development division. Out of all the respondents $21 \%$ of them are technical support executives and $17 \%$ of them are Network Engineers.

\section{Descriptive Analysis on Attributes of Dependent Variable}

The frequency analysis was used to analyses the attributes of the dependent variable and the summarized findings related to four selected dimensions of employee perception such as control, job security, job satisfaction and skills are given below.

1. About $58 \%$ of the respondents agreed with the strategic importance of outsourcing. It indicates permanent employees understand outsourcing as a significant tool of cost reduction.

2. Results indicate around one quarter of employees (27\%) agreed outsourcing helps increasing IT knowledge while majority did not believe outsourcing has an effect on increasing knowledge.

3. Overall $73 \%$ of the respondentsdid not consider outsourcing had improved communication within the department this indicates communication issues within the IT department impede relationship building process.

4. Overall $77 \%$ of the respondentsdidnot believe outsourcing helped to improve their personal skills.

5. About $37 \%$ of the respondents stated management did not frequently communicate them on organization outsourcing plans while $30 \%$ stated the opposite.

6. Overall $64 \%$ of the respondents believed outsourcing have not strengthened the control over projects and $17 \%$ believed it had strengthened the control. This elaborate the loosen control on projects at IT department and thisneeds to be improved.

7. More than half of respondents (58\%) had doubt about the quality of the deliverables since outsourcing. Results indicate a key problem, which should be considered seriously because quality is a very important factor of IT deliverable.

8. Altogether $72 \%$ of the respondents believed outsourcing led to reduce of permanent employees. The results indicate the permanent employees' uncertainty about their jobs.

9. Overall $44 \%$ of the respondents believed outsourcing affected to their promotions and $35 \%$ believed the opposite.

10. Results indicate majority (70\%) of therespondents had a perception of unsafe job position according to outsourcing.

11. About $33 \%$ of the respondents believed outsourcing affected to their current job role and $19 \%$ believed the opposite.

12. Overall $73 \%$ of the respondents stated outsourcing did not help to improve their morale.

13. About $65 \%$ of the respondents believed outsourcing has an impact on their compensation and benefits.

14. About $50 \%$ of the respondents dissatisfied on their jobs after outsourcing.

15. Little less than half of the respondents stated their motivation led to seek another job after outsourcing. 
The mean value of control, job security, job satisfaction, skills and overall employee perception

Table 1:-Mean values of the dimensions of employee perception

\begin{tabular}{|l|l|l|}
\hline Attribute & Mean Value & Standard Deviation \\
\hline Control & 2.67 & 0.554 \\
\hline Job Security & 2.53 & 0.651 \\
\hline Job Satisfaction & 2.46 & 0.541 \\
\hline Skills & 2.57 & 0.515 \\
\hline Employee perception & 2.56 & 0.412 \\
\hline
\end{tabular}

According to Table1 the mean values of all the dimensions of employee perception indicated disagreed preference. The mean value of overall employee perception is 2.5 with a standard deviation of 0.412 . Therefore, the current level of employee perception regarding IT outsourcing of thebank is not favorable.

\section{Hypotheses Testing}

The ANOVA test was used to analyse the relationship between independent and dependent variables at 0.05 significant levels.

Table 2:-Hypothesis Testing

\begin{tabular}{|l|l|l|l|}
\hline Hypothesis & Test & $\operatorname{Sig}(\mathbf{2}$ tailed $)$ at $\mathbf{0 . 0 5}$ & Results \\
\hline H1 & ANOVA & 0.230 & Not Supported \\
\hline H2 & ANOVA & 0.371 & Not Supported \\
\hline H3 & ANOVA & 0.833 & Not Supported \\
\hline H4 & ANOVA & 0.015 & Supported \\
\hline
\end{tabular}

According to the statistical findings $\mathrm{H} 1, \mathrm{H} 2$ and $\mathrm{H} 3$ are not supported but only $\mathrm{H} 4$ is supported. Therefore, it is concluded that the employees of different age levels have significantly different level of perception on IT outsourcing. However, different job roles, job experience, and educational and professional qualification have no significantly different level on perception on IT outsourcing. This result indicates outsourcing had mostly affected to aged group of 40-49 employees who are having considerable level of experience. Resulted employee age groups depicts they have been with the organization for a considerable time period and the present outsourcing setup had negatively affected their perception.

\section{Conclusion:-}

The study finding reveled the overall perception of employees towards IT outsourcing is negative. The ANOVA test proved that the employee perception towards IT outsourcing differ by Employees of different age levels. The result differ from the findings of Robinson (2016) which concludes perception of younger employees which having less time service mostly affected by outsourcing (Robinson, 2016).

\section{Recommendations:-}

Knowledge sharing is an activity which share skills, information and expertise among people. Knowledge sharing programs can be recommended to increase perception about skills on permanent employees. The employee perception about controls can be enhanced by applying feed forward controls, concurrent controls and feedback controls. The managers in the organization have a critical role to play to shape employees perception and engagement and make positive work environment and reduce uncertain perception of their job environment as well as lack of job satisfaction due to outsourcing. Further,there is a need to reevaluate employees and take more time to examine impact of outsourcing on different age levels. It is recommended conduct more knowledge sharing programs among departments to increase the level of perception on outsourcing. 


\section{References:-}

1. Anderson, C.R, \& Paine, F.T. (1975). Managerial Perceptions and Strategic behavior. Academy of Management Journal, 18, 811-23.

2. Ang, S. \& Slaughter, S.A.(2000). The Missing Context of Information Technology Personnel: A Review and Future Directions for Research. Framing the Domains of IT Management, Projecting the Future through the Past.

3. Ang, S., \& Straub, D.(1998). Production and Transaction Economies and IS Outsourcing: A Study of the U. S. Banking Industry. MIS Quarterly ,22(4).

4. Barber, P.J., \&Legge, D.(1976). Perception and Information. London. Methuen.

5. Barako, D., \&Gatere, B.(2008). Outsourcing Practices of the Kenyan Banking Sector. Curtin University of Technology, Australia.

6. Bear, G.G, Manning, M.A., \& Izard, C.E.(2003). Responsible behaviour: The importance of social cognition and emotion. School Psychology Quarterly, 18,140-157.

7. Becker, G.(1964). Human capital: A theoretical and empirical analysis with special reference to education. New York: Columbia University Press.

8. Berelson, B., \& Steiner, G.A.(1964). Human behavior: An inventory of scientific findings. New York, NY: Harcourt, Brace \& World.

9. Chang, Y.B .,\&Gurbaxani, V.(2012). Information Technology Outsourcing, knowledge transfer, and firm productivity: An empirical analysis.

10. Chen, L.H.(2008). Job satisfaction among information system (IS) Personnel. Computers in Human Behavior, 24, 105-118.

11. Cooper, C.L.(1999). Can we live with the changing nature of work? Journal of Managerial Psychology, 14,569572.

12. Dhar, S., \& Balakrishnan, B.(2006). Risks, benefits, and challenges in global IT outsourcing: Perspectives and practices. Journal of Global Information Management (JGIM.), 14(3), 9-89.

13. Duhamel, F., Gutierrez-Martinez, I., Picazo-Vela, S., \& Luna-Reyes, L. (2014). IT outsourcing in the public sector: A conceptual model. Transforming Government: People, Process and Policy, 8(1), 8-27. Available at: http://dx.doi.org/10.1108/TG-05-2013-0012.

14. European Central Bank.(2004). Report on EU banking structure, [online] Available at: https://www.ecb.europa.eu/home/search/html/index.en.html?q=+Outsourcing+2004. [Accessed 17 Jul. 2017].

15. Fill, C, \& Visser, E.(2017). The outsourcing dilemma: a composite approach to the make or buy decision Management Decision 138, No 1. Emeraldinsight.com.[online]

16. Fritsch, M, \&Wüllenweber, K.(2007). Firm-level determinants of Business Process Outsourcing Decisions. IRMA.

17. Fung, H.P.(2013). Using porter five forces and technology acceptance model to predict cloud computing adoption among IT outsourcing service providers. Internet Technologies and Applications Research ITAR, 1(2), 18-24.

18. Galanaki, E., Bourantas, D., \&Papalexandris.(2008). A Decision Model for Outsourcing Training Functions: Distinguishing Between Generic and Firm Job Specific Training Content. The International Journal of Human Resource Management.

19. Ganster, D., \& Rosen, C.(2013). Work stress and employee health: A Multidisciplinary review. Journal of Management, 39.

20. Gartner IT Glossary.com.(2017). Outsourcing Definition - IT Outsourcing - Gartner IT Glossary. [online] Available at: http://www.gartner.com/it-glossary/it-outsourcing. [Accessed20 Jul. 2017].

21. Gorla, N., \& Somers, T M.(2014). The impact of IT outsourcing on information systems success. Information \& Management.

22. Gray, J., Tomlin, B \& Roth, A.(2009). Outsourcing to a Powerful Contract Manufacturer: The Effect of Learning-by-Doing. Production and Operations Management., 18(5),487-505.

23. Hackman, J.R., \& Oldham, G.R.(1980). Work redesign. Reading, MA: Addison-Wesley.

24. ITmanagerdaily.(2017). IT Outsourcing: Make it work for your Business?. [Online].Available at: https://www.itmanagerdaily.com/it-outsourcing. [Accessed20 Jul. 2017].

25. Kanfer, R., \& Ackerman, P.L.(2004). Aging adult development and work motivation. Academy of Management Review, 29, 440-458.

26. Lacity, M. \& Willcocks, L.(2012). Outsourcing business and I.T. services: The evidence of success, robust practices and contractual challenges. Legal Information Management,12(1),2-8.

27. Langton, N., \& Robbins, S.(2006). Organizational Behavior. Toronto: Pearson Prentice Canada. 
28. Lopez, J.(2004). Outsourcing by Financial Services Firms: The Supervisory Response. Federal Reserve Bank of San Francisco. [online].Available at: http://www.frbsf.org/economic-research/publications/economic letter/2004/november/outsourcing-by-financial-services-firms-the-supervisory-response/.[Accessed19 Jul. 2017].

29. Louis, L.(2002). Employee Perceptions of Outsourcing of Information Technology Operations: An Empirical Investigation. Nova South Eastern University.

30. Madsen, S., Miller, D., \& Cameron, J.(2005). Readiness for organizational change: do organizational commitment and social relationships in the workplace make a difference?. Human Resource Development Quarterly, 16(2),213-234.

31. Maigua, A.(2015). Information technology outsourcing and employee perceptions at Keswick books and gifts limited in Kenya. Hdl.handle.net. [online] Available at: http://hdl.handle.net/11295/93054. [Accessed 21 Jul. 2017].

32. Palvia, P., \&Parzinger, M.(1995). Information systems outsourcing in financial institutions. In Khosrowpour, M. (Ed.), Managing Information Technology Investments with Outsourcing, Harrisburg, PA: Idea Group Publishing, 129-154.

33. Piyasena, K.K.L.(2006). Outsourcing of Banking Activities: Emerging trends and Challenges.

34. Pujals, Ayadi, Rym\&Georges(2004). Banking Consolidation in the EU: Overview and Prospects. CEPS Reports in Finance and Banking No. 34, 1 May 2004 - Archive of European Integration. Aei.pitt.edu [Online] Available at:

35. Robinson, J .R.(2016). Role of Outsourcing in Stress and Job Satisfaction. Walden University, College of Management and Technology.

36. Rose-Anderssen, C., Baldwin, J., \& Ridgway, K.(2011). Commercial aerospace supply chains. Journal of Manufacturing Technology Management, 22(1), 66-89.

37. Solinger, O.N., Van Olffen, W., \& Roe, R.A.(2008). Beyond the Three-Component Model of Organizational Commitment. Journal of Applied Psychology,93, 70-83.

38. Vithessonthi, C.(2005). A Perception-Based View of the Employee: A Study of Employees' Reactions to Change. University of St. Gallen, Graduate School of Business Administration.

39. Winkleman, M.(2017). Time to Do or Die. Journal of Business Strategy, 14(5). 